\title{
Creating a virtuous cycle for increased trust in local government
}

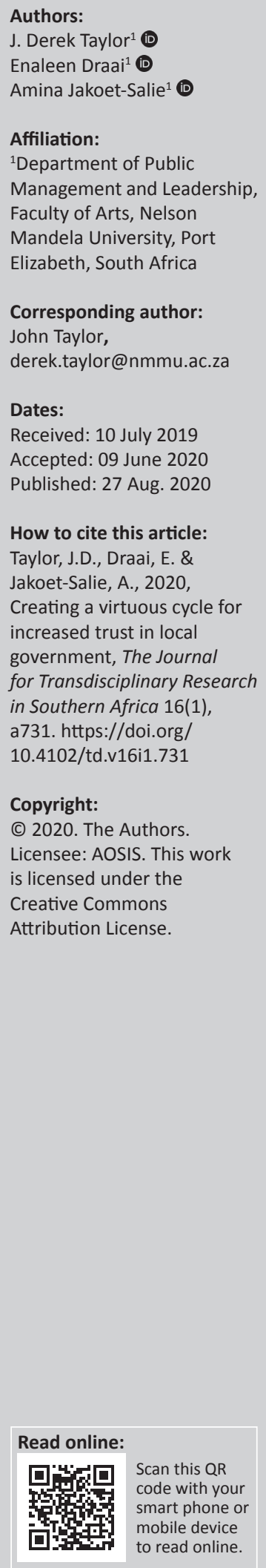

Authors:

Affiliation:

Department of Public

Faculty of Arts, Nelson

Mandela University, Por

beth, South Africa

John Taylor,

Dates:

Received: 10 July 2019

Accepted: 09 June 2020

this article:

Creating a virtuous cycle for

for Transdisciplinary Research

Southern Africa 16(1)

a731. https://doi.org/

Copyright:

(c) 2020. The Authors.

is licensed under the

Creative Commons

Attribution License.

mobile device

to read online.
After the advent of the first free and fair elections in South Africa in 1994, access to municipal services became a right for all residents. Now, more than ever, the inclusion of previously disadvantaged communities is being intensified. However, the delivery of services often remains inadequate, eliciting increasing protests throughout the country. Protests, which are often the last resort by communities, are indicative of declining levels of trust in local government. It becomes problematic when trust in communication channels and public participation strategies is limited, co-production of services is impeded and the possibility of increasing such trust is, in turn, negatively affected. This study used a mixed-methods approach including both quantitative and qualitative research techniques to validate the posed research questions and authenticate the presented problem statement. The triangulation approach allowed for effectively engaging the strengths of both research methodologies. The findings of the study revealed that as a result of communities' increasing lack of trust and confidence in local government, service delivery protests are increasing. The study further indicated that communities in the Nelson Mandela Bay Municipality (NMBM) are generally not well informed about the development plans of the municipality and do not adequately participate in local government activities. The study provides recommendations to augment trust in local government communication channels to improve public participation that could lead to the co-production of services. In this way, the study asserts that trust can be enhanced in what amounts to a virtuous cycle.

Keywords: trust; public participation; co-production; participatory democracy; governance; communication.

\section{Introduction}

Post-1994, access to municipal services in South Africa was no longer regarded as a privilege meted out to communities based on race, but rather as the right of all residents. Thus, the need to extend such services to citizens who were previously excluded became paramount. Local government has the mandate to render basic services within defined geographical areas that aim to enrich communities' conditions of life (Davids, Theron \& Maphunye 2005:59). In conjunction with this mandate, the local government is also responsible for promoting the principles of democracy (Davids et al. 2005:59). Yet, recent studies have revealed that the redress hoped for after 1994 has not been adequately directed and local government has failed to address the service needs of those previously disadvantaged. That is, despite the national government having injected significant financial resources to promote social and economic development by providing basic infrastructure and services, many municipalities have failed to adequately address the basic needs of their communities (Jakoet-Salie 2018:15). Furthermore, certain municipalities have failed to resolve problems related to the local governance, particularly pertaining to effective communication between the local government and the citizenry. Correlatively, in these failing municipalities, public participation is low; there is both a tendency amongst citizens to have lower trust levels in government and, in the long run, an increase in service delivery protest actions. These problems suggest that where there is little trust in government communication channels, there is also little public participation, co-production of services is impeded and the possibility of such trust is thereby negatively affected, in what amounts to an increasingly self-destructive cycle (Jakoet-Salie 2018:56).

In this study, it is advanced that active public participation between municipalities and ward committees may foster the improved co-production of services. In this regard, the proper channels of communication can identify the specific service needs of communities. The means of potential co-production solutions could then be established. In other words, a virtuous cycle could be created whereby municipal councils become more aware of what services and concerns they 
need to address so that by delivering these services efficiently and effectively, municipalities can restore the trust of communities in local government (Jakoet-Salie 2018:212).

\section{Community protest action and communication within local government}

Section 152 of the Constitution of the Republic of South Africa, 1996, stipulates the objectives of local government, which include the establishment of community participation and community consultation in local government matters. In terms of Section 152 of the Constitution, the objectives of local government are to: (1) provide a democratic and accountable government for local communities; (2) ensure the provision of services to communities in a sustainable manner; (3) promote social and economic development; (4) promote a safe and healthy environment; and (5) encourage the involvement of communities and community organisations in the matters of local government.

Community involvement could, therefore, play an important developmental role by making sure that municipalities regard citizens as the focal point of local development initiatives. The 1996 Constitution is unique in South Africa's history because it acknowledges the local sphere of government as a distinctive, interdependent and interrelated confederate in intergovernmental relations. However, despite South Africa taking a significant and positive stride towards the promise of developmental local governance after 1994, most municipalities are still plagued by significant challenges that have sparked a wave of national service delivery protests. These protests are summarised in Figure 1.

From Figure 1, it is evident that service delivery protests are still a regular occurrence in the lives of many South Africans; however, what the figure does not show is the increasing intensity of the protests. This increased intensity is a

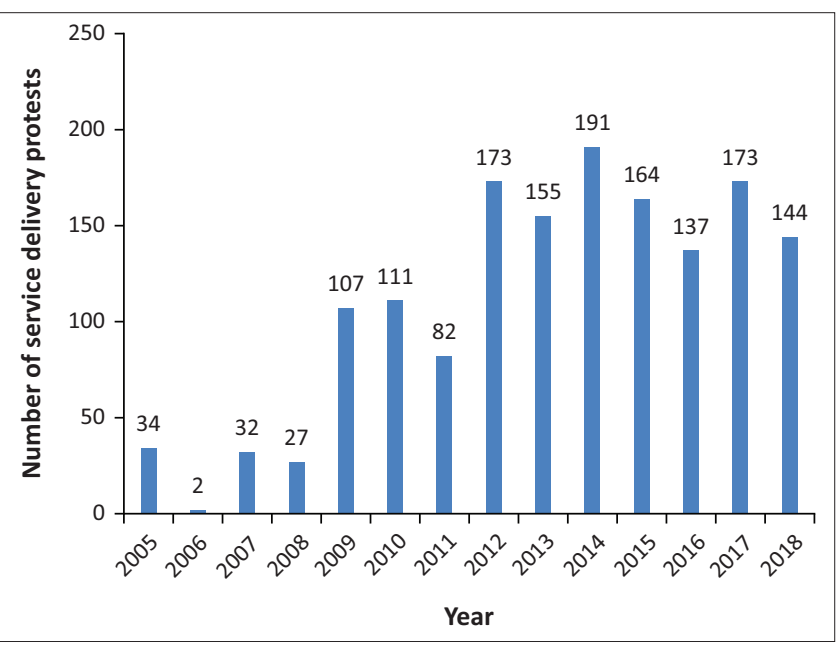

Source: Statistics South Africa (STATS SA), 2018, Major service delivery protests by 2005 2018, viewed 11 February 2019, from http://www.statssa.gov.za/publications

FIGURE 1: Major service delivery protests by 2005-2018. perceived consequence of municipalities not responding satisfactorily in addressing respective community and service delivery issues. This unsatisfactory response by the local government further fuels the fires of community discontent, and the negative cycle continues. Interestingly, not only has the number of protests increased, but these protests are more violent in nature.

Some of the integral gauges in evaluating the adjustments of local government are the following: (1) the existing insights and daily experiences of communities, and, more specifically, (2) whether or not there has been progress in the services delivered to them (Tippett \& Kluvers 2010:23). It is fundamentally important to restore trust and confidence in communities by enhancing the co-production of services, as consistently poor service delivery diminishes trust in local government. This improvement requires effective channels of communication in order for municipalities to better understand exactly what services are deemed crucial by communities (Jakoet-Salie 2018:50).

\section{Structures and strategies to enhance co-production of trust}

The Local Government: Municipal Structures Act 117 of 1998 introduced a key vehicle for public participation, namely, Ward Committees. The ward committee system was first introduced in South Africa in 2001 when the former State President, Thabo Mbeki, sought to strengthen community participation (Ward Committee Resource Book 2005:32). The policies and legislation governing the role of Ward Committees stipulate that '...such process[es] thus reinforces two of the fundamental mechanisms of sustainable democracy, which is participation of the people and accountability of local government' (Ward Committee Resource Book 2005:39). Ward Committees are, thus, regarded as one of the main mechanisms available to municipalities and communities to heighten public participation within local government (Jakoet-Salie 2018:54). However, Ward Committees face a number of challenges, as their powers are limited to only advising communities, and the relevant councillors often lack information and understanding of their work. According to Karamoko and Jain (2011:Online), findings by the Local Democracy, Peace and Human Society (LDPHS) indicate that many ward councillors in many areas are not leading, directing or, in some areas, not even attending ward committee meetings and, as a result, there is often no consultation with communities on matters that are affecting them.

In terms of Section 73(2) of the Local Government: Municipal Structures Act 117 of 1998, public participation is an essential factor for affecting and enhancing accountable governance and is often driven by Ward Committees, as mandated, to facilitate open communication channels between municipalities and communities. Section 19 of the Act further prescribes that municipalities should develop adequate tools that enable them to consult with communities and community groups in their performance and implementation of their powers. The Act also requires that 
municipalities must annually review the needs of communities against available funding. Municipalities have been battling to successfully fulfil the implementation of these legislative prescriptions.

Draai and Raga (2012) contend that levels of trust in public services are defined by their perceptions of the willingness and expedience with which the government responds to issues that citizens deem critical. These issues would include areas such as crime, poverty or poor client services. Accordingly, high levels of trust are attained by overtly positive performances by local government, whereby citizens experience change, whilst low levels of trust, or even distrust, occur when citizens receive poor service delivery.

Thus, whilst it might be true that protests turn to violence only after formal channels have been exhausted, it is also possible that the underlying problem may also include insufficient public participation and co-production at the local government sphere. Mle (2014:61) asserts that citizen participation in the affairs of a municipality promotes a sense of pride and belonging within citizens and can work to eliminate an 'us' (communities) versus 'them' (municipality) mentality. Therefore, if the aforementioned nation-wide service delivery protests are indicative of the decline in public trust in the government, it is crucial that this loss of trust is improved through the establishment of more effective communication channels between communities and municipalities (Jakoet-Salie 2018:58).

\section{Theorisations of public participation and co-production}

Citizens who are not actively involved in municipal undertakings tend to have a more negative perception of government and its institutions. Conversely, co-production through the involvement of citizens in the delivery of public services is believed to foster trust. Ostrom (1996:1073) defines co-production as '...the process through which inputs used to provide goods or services are contributed by individuals who are not in the same organisation'. In addition to co-production, the service delivery process itself acts as an integral tool for evaluating the service in its entirety and, thus, communities that receive a service should be involved in designing the service based on their real needs (Bovaird \& Loeffler 2012a).

\section{Systems theory}

As previously stated, the legacy of apartheid imposed upon the new South Africa numerous challenges, which include poverty, inequality and the demand for greater access to basic public services. The post-apartheid government, therefore, sought to address these challenges by enshrining constitutional rights to basic services and maintaining that service delivery programmes be funded and properly implemented (Jakoet-Salie 2018:59). To understand this new governmental approach to service delivery, systems theory has been chosen and forms the basis of the theoretical framework to study the interactions and relationships between the various role-players in government and their external environment. Draai (2016:21-32) describes a system as 'a set of interrelated components whereby the system uses inputs (stimuli from the environment), which it then converts into outputs and obtains feedback concerning the impact of its responses'. Similarly, Pestoff, Brandsen and Verschuere (2013:368) distinguish between the input and output sides of a political-administration dichotomy by stating that citizens make demands and give support on the input side of the political system, whilst they are subject to public decisions and receive goods and services on the output side. According to Sithomola and Auriacombe (2018:87), systems theory facilitates the role-players in public decision-making to contextualise and comprehend the status quo and expand their viewpoint on situations and what the impact will be on the system and environment.

Consequently, co-production has become an important factor for effective service delivery in South Africa and should be conducted via transparent and accountable relationships between politicians, public officials and communities. Pestoff et al. (2013:24) argue that citizen involvement in service delivery is highly dependent on the significance and magnitude of the service provided and the following questions should be considered in relation thereto: 'Is the important service for them, their family, loved ones, a relative, a friend or not? Does it have a direct impact on their life or does it only have an indirect effect?' Furthermore, Lindquist, Vincent and Wanna (2013:76) define a 'citizen' as part of the combined 'we' who plays a role in establishing what government should do through being involved in all the practices of democracy.

From the above discussion, it can be inferred that increased co-production should positively affect the public's perception of the value of services rendered to them by local government. It is therefore recommended that citizens and community groups be consulted in so far as municipal affairs and development in their municipal areas are concerned. Correlatively, John et al. (2011) state that the reasons for citizens engaging in co-production are multifaceted, and their co-productive behaviour is determined by two factors: (1) their willingness to co-produce (acting as 'motivators') and (2) their ability to do so (acting as 'facilitators').

In their survey of 1800 adult South Africans, the pan-African, non-partisan research network, Afrobarometer (2016), in association with the Institute for Justice and Reconciliation and Plus 94, found that involving citizens in service delivery matters improves trust levels and confidence in local government (Afrobarometer Dispatch No. 90 2016). Conversely, Askvik and Bak (2005:80) contend that communities with low levels of trust tend to resist municipal governance and support rent and service boycotts.

The 2017 Edelman Trust Barometer indicates that, internationally, the South African government is least trusted by its populace, with only $15 \%$ of citizens verifying their trust in government (Rittenberry 2018:Online). A year 
later, the 2018 Edelman Trust Barometer reported that more than 33000 people were surveyed between October and November 2017. The countries surveyed included, amongst others, the United States of America, the United Kingdom, Germany and Brazil. Globally, more than half (56\%) of respondents had lost trust in government leaders (Rittenberry 2018:Online). In South Africa, 86\% of those surveyed harboured distrust towards the government. These responses indicated a 1\% improvement from 2017, however South Africa was still placed at the bottom of a list of 28 surveyed countries (Somdyala 2018:Online). These statistics support the notion of the research that communication channels need improvement in order for trust to be restored.

Bovaird and Loeffler (2016:28) propose that the move towards co-production can be conceptualised as a change from 'public services FOR the public' towards 'public services BY the public'. However, these authors acknowledge that systemic barriers exist (see Table 1), which prevent co-production from being used in public services. Table 1 identifies the barriers and initiatives that have been used by the current South African government and how, as previously indicated, despite these implemented measures, service delivery still remains problematic.

\section{Elements of participatory democracy and community participation}

Ward Committees are positioned to facilitate participatory democracy by disseminating information, helping to rebuild partnerships for improved service delivery and solving problems at ward level (Mafunisa \& Xaba 2008:452). As a developing country, South Africa possibly has one of the most advanced policies on participatory local governance in the world (JakoetSalie 2018:60). Democracy and public participation are closely connected. This progressive intent is further enhanced by the importance of public participation, as outlined in the 1998 White Paper on Local Government; the White Paper on Transforming Public Service Delivery, 1997 (The Batho Pele Principles); the Local Government: Municipal Structures Act 117 of 1998; the Local Government: Municipal Systems Act 32 of 2000 and the Local

TABLE 1: Barriers to co-production.

\begin{tabular}{ll}
\hline Barriers to co-production & South African government initiatives \\
\hline $\begin{array}{ll}\text { Political and specialist hesitancy } \\
\text { to lose status and 'control' }\end{array}$ & $\begin{array}{l}\text { - White Paper on Local Government } \\
\text { - White Paper on Transforming Public Service } \\
\text { Delivery }\end{array}$ \\
$\begin{array}{ll}\text { L Lock of mechanisms that local } \\
\text { communities can use }\end{array}$ & $\begin{array}{l}\text { - National Policy Framework on Public } \\
\text { Participation } \\
\text { - Integrated Development Planning } \\
\text { - User ratings of services (especially online or at } \\
\text { the point of service) }\end{array}$ \\
$\begin{array}{ll}\text { - Local Government Structures Act } \\
\text { Lack of motivation or self- } \\
\text { assurance on the part of local } \\
\text { communities }\end{array}$ & \begin{tabular}{l} 
- The Ward Committee Resource Book \\
\hline
\end{tabular}
\end{tabular}

Source: Pestoff, V., Brandsen, T. \& Verschuere, B., 2013, New public governance, the third sector and co-production, p. 48, Routledge, London; adapted by Jakoet-Salie (2018) Pestoff,
V., Brandsen, T. \& Verschuere, B., 2013, New public governance, the third sector and V., Brandsen, T. \& Verschuere, B., 2013, New public governance, the third sector and
co-production, Routledge, London; adapted from Jakoet-Salie, A., 2018, 'Co-production of co-production, Routledge, London; adapted from Jakoet-Salie, A., 2018, 'Co-production of
trust for effective local governance: A case study of Nelson Mandela Bay Municipality', Unpublished thesis for the Degree of Doctor of Philosphiae, Faculty of Arts, Nelson Mandela University, Port Elizabeth.
Government: Municipal Finance Management Act 56 of 2003. The Local Government: Municipal Systems Act 32 of 2000 also further purports that communities have the directive to participate in any public consultation and decision-making processes in local government, for example, ward committees, budget consultations, ward meetings and Integrated Development Plan (IDP) forums.

In 2005, the National Policy Framework on Public Participation was published and defines participation as '... an open, accountable process through which individuals and groups within selected communities can exchange views and influence decision-making' (Department of Provincial and Local Government 2005:1). In their capacities as citizens and voters, municipalities are mandated to engage with citizens and community groups in matters of municipal development in their area (White Paper on Local Government 1998:4-5). The National Policy Framework on Public Participation views public participation as the democratic process of engaging people in decisions that affect their communities, and which allows citizens to be active role-players in the development and management of services that affect their lives (Department of Provincial and Local Government 2005:1). However, whilst such aforementioned policies promote cooperation, elected public representatives have largely not been successful in bringing about visible and fundamental changes in their relations with the public and institutions of governance at the local sphere (Jakoet-Salie 2018:60). Instead, elected officials' participation has benefited mainly those who have access to resources and are better organised (Jakoet-Salie 2018:60).

Once a political party is voted into power, according to their election manifesto, the government is expected to deliver the services that it has promised, and citizen participation is critical to this process. As part of public participation, Van der Waldt et al. (2014:27) assert that citizens have the right to protest and gradually demand more interaction with their local governments when they, as beneficiaries of services, regard these services as inefficient and ineffective.

Without public participation, a democratic government cannot function as a democracy because positive public participation becomes stifled and the public is not actively involved in governmental decisions and processes. To illustrate the importance of public participation, Bovaird and Loeffler (2003:193) have developed a typology of public participation, illustrated in Figure 2, that highlights the importance of 'consultation', 'listening', 'being in touch

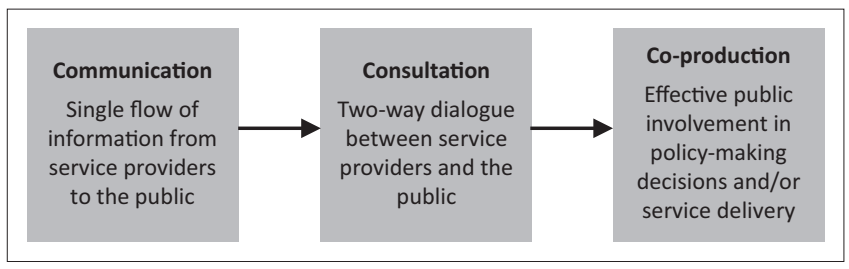

Source: Bovaird, T. \& Loeffler, E., 2016, 'What has co-production ever done for interactive governance?', in J. Edelenboos \& I. Van Meerkerk (eds.), Critical reflections on interactive governance, Edward Elgar, Cheltenham.

FIGURE 2: Public participation spectrum. 
with the people', 'involving users' and strengthening 'accountability to local communities'.

According to Bovaird and Loeffler (2016), involving citizens in policy-making and the planning and provision of services is not a modern-day concept because co-production includes '...professionals and citizens making better use of each other's assets, resources and contributions to achieve better outcomes or improved efficiency'. The South African local government system is there to serve citizens and if that service is failing, even though there are good structures in place, trust levels amongst citizens will continue declining. Despite the fact that the new local government system is already in its second decade, there are still signs and trends to indicate that the majority of South African municipalities are failing in delivering on their local government mandate. An apathetic public that does not take part in governance provides a fertile ground for widespread corruption, fraud and maladministration. In addition, according to Bovaird and Loeffler (2003:200), engaging citizens in policy-making and the design and delivery of services is increasingly being seen as a key to good governance.

\section{Defining governance relative to trust}

From early writings, Keohane and Nye (2000:37) define governance as '...the processes and institutions, both formal and informal, that guide and restrain the collective actions of a group'. Pestoff et al. (2013:103) state that 'the distinct way to warrant good governance is by institutionalising powerful accountability mechanisms that hold every public official responsible for his or her actions as a public servant'. According to Van der Waldt et al. (2014:4), good governance implies the presence and account of all groups in a municipality by implementing the integrity and transparency of local government actions in the pursuit of goals. Conversely, poor or bad governance has often been shown to undermine the legitimacy of the government. The issue of mistrust in governmental ability can permeate nearly every sector of a society, so trust is a crucial component required for the effective functioning of all spheres of government. Draai and Raga (2012) state that a minimum level of trust is important for the maintenance of, and aspiration to, levels of good governance, as good governance is directly determined by the levels of trust held by citizens in both the areas of political authority and public service, as well as in terms of officials' accountability and citizen interaction with government.

According to Fukuyama (1995:129), trust is defined as an interpersonal concept that informs how citizens view one another in terms of what they know of one another. Draai (2016:158) further states that trust in the political sphere and within public service is conditional; it 'ebbs and flows' according to experience and perception and is behavioural, depending on how citizens assess the actions of political leaders and/or the performance of public officials. Pillay
(2017:33) states that political trust is founded on good governance that is based on the existence of ethical codes and accountability procedures, as citizens expect good and ethical governance in all spheres of life. Furthermore, Pillay (2017:33) affirms that political trust is not won by fancy or verbose party manifestos, or pre-election promises but rather by politicians' and administrators' responses to these election manifestos. It is when citizens believe or realise that manifestos and promises are forgotten, that mistrust emerges.

Draai (2016:158) also contends that trust within a democratic governance system is complex and multidimensional, particularly because of its social, political and organisational ramifications. The author defines social trust as the confidence that citizens in a community have in each other (Draai 2016:158). This type of trust permeates all segments of society. Shaidi (2013:279) states that it is clear that communities have lost trust in the engagement process with their government and that public participation, as legislated, works below anticipated optimal levels. In this regard, Shaidi (2013:279) contends that the citizens have now chosen their own way of talking to the government, namely, via violent service delivery protests to show their dissatisfaction.

Political trust is generally partisan and relates to the assessment by citizens of the levels of credibility and perceived integrity of political leaders, especially in relation to the ruling party (Draai 2016:158). This assessment of credibility is based on organisational aspects that include a party's commitment to its political manifesto by demonstrating positive performance in political leadership and oversight responsibilities (Draai 2016:158).

Trust is, therefore, an essential pre-requisite for good governance. In the public sector, good governance refers to effective arrangements put in place to ensure that the intended outcomes for stakeholders are defined and achieved, for example, political, economic, social, environmental and administrative arrangements (Fourie 2015:106).

In response to governance challenges, the National Development Plan (NDP) was adopted in 2012 as a regulatory policy to guide governmental departments towards realising political and governmental policy goals by 2030 (Draai 2016:121). The NDP - Vision 2030 (National Planning Commission [NDP] 2011) articulates a vision for South Africa to 2030 and provides an overarching framework for further planning and delivery by actors from every sector of society to eliminate poverty and reduce inequality. Chapter 13 of the NDP establishes the goals that must be met so as to construct a proficient and developmental state in South Africa. These objectives are as follows:

- to create a state that is proficient at portraying a developmental and transformative role

- to have an engaged public service that is disconnected from undue political interference

- to provide all staff the required skills and competence that is essential to fulfil their jobs 
- to improve intergovernmental relations by implementing a more pro-active approach

- to ensure transparent governance structures and possess stable leadership that will enable state-owned initiatives to achieve their developmental potential (Botha et al. 2015:288).

As previously stated, Ward Committees and public participation are regarded as key tools to promote both the co-production of services within municipalities and to enhance stakeholders' commitment to participatory governance. However, certain communities still feel isolated and disengaged from decision-making processes and feel disempowered in terms of their capacity to influence the affairs of their local municipality.

\section{Findings of the empirical study}

The empirical component of this study restricted its geographical focus to the Nelson Mandela Bay Municipality (NMBM), which has a population of 1263 051, as reported in the 2016 Community Survey (Stats SA 2016). The NMBM provided the empirical base for the data collection from which reliable conclusions could be derived for purposes of this study. For the purpose of this research, the quantitative research approach was regarded as best suited for examining the data related to the studied ward councillors (60), members of the Executive Mayoral Committee (10) and senior municipal officials (50). The 60 ward councillors represent the 60 wards in the area of jurisdiction of the NMBM. The qualitative data were generated from focus group interviews with 23 NMBM ward committee members, whereby useful insights relating to trust, and citizen and public participation were obtained using questions extracted from an interview schedule. The focus group interviews with ward committee members were conducted to distinguish whether or not citizens would continue to disengage from the government no matter how much progress is made within the NMBM, as well as whether or not the municipality can increase the trust of citizens in government by improving services and better engaging community members. Collectively, the findings of the quantitative and qualitative research were used to generate final findings and conclusions.

The findings of this study disclosed some thought-provoking, some weak and some neutral responses to the statements presented. In particular, responses indicated communities' fading lack of trust and confidence in local government, increased service delivery protests, and that citizens are more likely to participate in matters that will directly improve their well-being. Table 2 indicates that a total of $84.3 \%$ of the respondents agreed with the statement that service delivery protests were intensifying as a result of the fading lack of trust in government, whilst $11.4 \%$ were undecided and $4.3 \%$ responded negatively.

Table 3 indicating the relationship between citizen engagement in decision-making issues and trust levels
TABLE 2: As a result of communities' fading lack of trust and confidence in local government, service delivery protests are increasing.

\begin{tabular}{lcc}
\hline Likert scale & Frequency & $\mathbf{\%}$ \\
\hline Strongly disagree & 1 & 1.4 \\
Disagree & 2 & 2.9 \\
Neutral & 8 & 11.4 \\
Strongly agree & 45 & 64.3 \\
Agree & 14 & 20 \\
\hline Total & $\mathbf{7 0}$ & $\mathbf{1 0 0 . 0}$ \\
\hline
\end{tabular}

TABLE 3: Engaging citizens in decision-making issues will increase trust levels amongst citizens.

\begin{tabular}{lcc}
\hline Likert scale & Frequency & $\mathbf{\%}$ \\
\hline Agree & 38 & 54.3 \\
Strongly agree & 32 & 45.7 \\
\hline Total & $\mathbf{7 0}$ & $\mathbf{1 0 0 . 0}$ \\
\hline
\end{tabular}

reflects that all respondents agreed that by engaging citizens in decision-making issues, trust levels amongst citizens will increase. Open communication between citizens and officials was paramount regarding decision-making within the NMBM. If the public was involved in the decision-making processes, they would have a better understanding of how the municipality functions.

The set of questionnaires administered to the aforementioned 120 politicians and officials did not comprise only quantitative questions or statements but also contained open-ended questions. The opinions of ward councillors, Mayoral Committee members and senior municipal officials are important in determining the causes of the declining levels of citizen trust in local government and the possible solutions thereof. The responses from the surveyed politicians and officials commonly identified the following reasons, in descending order (from most important to least important), behind the service delivery protests in the NMBM:

- unfilled election promises made by politicians

- political interference

- lack of involvement by communities in development programmes

- lack, or slow delivery, of basic services

- high rate of unemployment

- frustration of long-outstanding services

- poor communication, public participation and lack of effective information-sharing sessions

- maladministration of resources and funds

- lack of trust in local government in delivering quality services (e.g. poor housing and poor public healthcare).

Furthermore, the findings of the empirical study revealed that service delivery protests are used as a channel by communities to express their dissatisfaction and distrust in local government regarding the slow pace or lack of service delivery. However, ward councillors, Mayoral Committee members and senior municipal officials stated that a change in political leadership would not ultimately lead to trust unless all the role-players in decision-making processes worked together. These groups of participants also 
reaffirmed the important need to address and improve the communication channels between political and administrative staff and citizens.

From the presented findings, it became clear that open communication between citizens and officials is paramount for effective decision-making within the NMBM. If the public became more involved in decision-making processes, they would have a better understanding of how the municipality functions and officials would better understand the needs of the community. According to Bianchi, Bovaird and Loeffler (2017), co-production brings together paid public officials and citizens who may act as individuals, households or communities. However, public governance principles need to be defined and operationalised to provide the 'rules of the game' and the agreed-upon processes by which citizens and officials work together (Bianchi et al. 2017). The Department of Performance Monitoring and Evaluation implicitly states that citizens' experiences and opinions must be included in the government's monitoring system, and underscores the government's need to be responsive to citizens' opinions because it is required by law and policy (DPME 2013).

\section{Recommendations: Creating a virtuous cycle}

It is acknowledged that it is not possible for governments to exist in solitude when community alienation with the government is rampant and additional groups within communities are gradually forming and developing (Lindquist et al. 2013). It is crucial, therefore, for local governments to connect with citizens and their needs. In South Africa, the introduction of public participation has demonstrated itself as a key concept towards the shaping of a participatory democratic and developmental state. The empowerment of communities can only happen when communities are given the opportunities

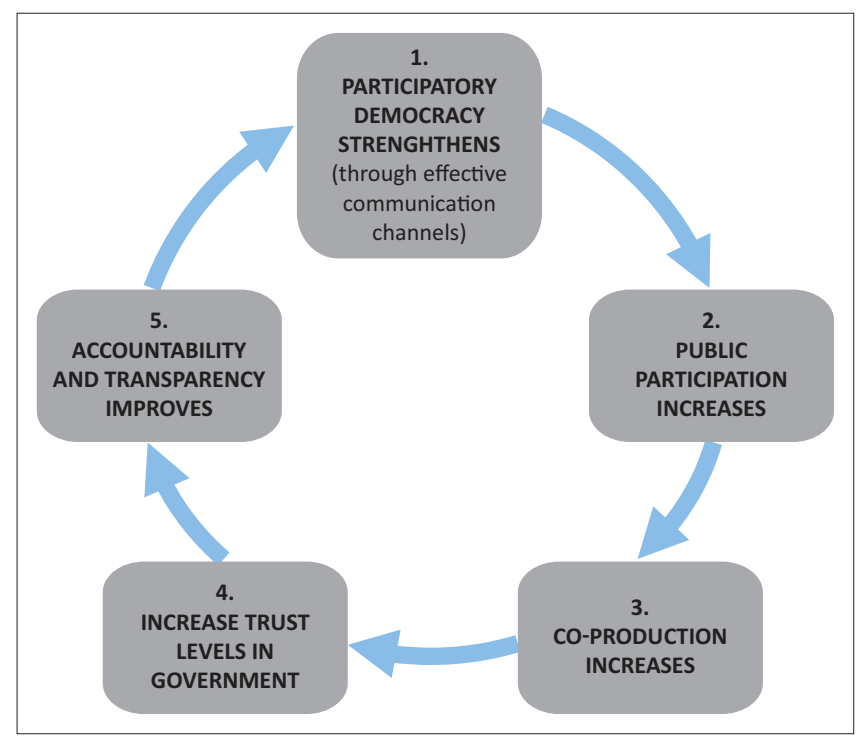

FIGURE 3: Virtuous cycle of public participation, co-production and trust. and the resources to actively engage in matters of local government decision-making affairs.

Heightened levels of co-production may have a positive impact on the public's level of trust and confidence in local government by ensuring that councillors play a more meaningful role in ensuring accountability. This accountability, in turn, could lead to further mobilising co-production in the community, thereby creating a virtuous cycle (see Figure 3). Conversely, this cycle may undermine good governance when it reverses because a decrease in public trust could inhibit participation, which, in turn, could weaken participatory democracy and potentially lead to a decrease in transparency and accountability (Jakoet-Salie 2018:65).

Through their legislative framework and co-production of services, municipalities may provide citizens with the opportunity to indicate what their needs are and to endeavour to take the necessary action to address these needs. Government should be acknowledged for putting current structures in place, but it still tends not to adequately incorporate citizens' opinions and experiences in its interventions or improvement programmes (Davis, Roberts \& Struwig 2016). Co-production necessitates that nobody knows better which public services are most important for citizens' welfare than the service users (citizens) themselves and the communities wherein they live. Citizens' involvement in identifying problems and setting priorities could motivate a greater sense of community involvement, and thereby facilitate greater co-production between local government officials and councillors in setting common goals, which, in turn, could be an integral trust-enhancing device (Askvik \& Bak 2005:98). According to John et al. (2011), '...citizen co-producers are not Pavlovian respondents to carrots and sticks'. That is to say, citizens would rather participate in government activities based on what the government has to offer and if their own interests are amplified.

\section{Conclusion}

As an ongoing call to urgently address community needs, municipalities should find sustainable ways to meet needs and improve the quality of communities' lives. It is, therefore, imperative that municipalities, in future, involve citizens more fully in service delivery by creating a sense of community collaboration to compensate for previous municipal failures in this regard. It is an observable fact that services that do not lead to improvements in the quality of life of communities and citizens are more likely to be challenged and more likely to engender mistrust in government (Jakoet-Salie 2018:67).

South African citizens need to become more involved in the future of their municipalities so that both citizens and the public sector contribute towards effective service delivery and, in due course, (re)gain trust in government. 


\section{Acknowledgements}

\section{Competing interests}

The authors have declared that no competing interests exist.

\section{Authors' contributions}

All authors contributed equally to this work.

\section{Ethical consideration}

Ethical approval to conduct the study was obtained from the relevant standing committee (Faculty Postgraduate Studies Committee [FPGSC] - Faculty of Arts) at the Nelson Mandela University (reference no. H/17/ART/PML-005 granted on 07 June 2017).

\section{Funding information}

This research received no specific grant from any funding agency in the public, commercial or not-for-profit sectors.

\section{Data availability statement}

Data sharing is not applicable to this article as no new data were created or analysed in this study.

\section{Disclaimer}

The views and opinions expressed in this article are those of the authors and do not necessarily reflect policy or position of any affiliated agency of the authors.

\section{References}

Afrobarometer, 2016, viewed 26 November 2017, from http://www.afrobarometer. org/publications/ad90-south-africa-citizens-trust-president-political-institutionsdrops-sharply.

Askvik, S. \& Bak, N., 2005, Trust in public institutions in South Africa, Ashgate Publishing Limited, Aldershot.

Bianchi, C., Bovaird, T. \& Loeffler, E., 2017, 'Applying a dynamic performance management framework to wicked issues: How coproduction helps to transform young people's services in Surrey County Council, UK', International Journal of Public Administration 40(10), 833-846. https://doi.org/10.1080/01900692.2017.1280822

Botha, C., Brand, D., Engelbrecht, M. \& Van Eijbergen, R., 2015, South African governance, Oxford University Press, Cape Town

Bovaird, T. \& Loeffler, E., 2003, Public management and governance, Routledge, New York, NY.

Bovaird, T. \& Loeffler, E., 2012a, 'We're all in this together: User and community coproduction of public outcomes. A Discussion paper', Institute of local government studies, Birmingham.

Bovaird, T. \& Loeffler, E., 2012b, 'From engagement to co-production: The contribution of users and communities to outcomes and public value Voluntas', Springer, New York, NY.

Bovaird, T. \& Loeffler, E., 2016, 'What has co-production ever done for interactive governance?', in J. Edelenboos \& I. Van Meerkerk (eds.), Critical reflections on interactive governance, pp. 254-277, Edward Elgar, Cheltenham.

Davids, I., Theron, F. \& Maphunye, K.J., 2005, Participatory development in South Africa: A development management perspective, Van Schaik Publishers, Pretoria.

Davis, Y.D., Roberts, B. \& Struwig, J., 2016, 'Fostering an inclusive development agenda in South Africa: Citizen voices and government policy responses', viewed 01 September 2017, from http://hdl.handle.net/20.500.11910/9562

Department of Performance Monitoring and Evaluation (DPME), 2013. A framework for strengthening citizen-government partnerships for monitoring frontline service delivery, DPME, Pretoria.
Department of Provincial and Local Government, 2005, National policy framework on public participation, Government Printer, Pretoria.

Draai, E.E., 2016, A practical introduction to public management, Oxford University Press, Cape Town.

Draai, E.E. \& Raga, K., 2012, 'Quality public services: A South African citizen perspective', Africa Insight 42(2), 184-199.

Fourie, D., 2015, 'Good governance in public-private partnerships approaches and applications: A South African perspective', African Journal of Public Affairs 8(1), 108-116.

Fukuyama, F., 1995, Trust: Social virtues and the creation of prosperity, Free Press, New York, NY.

Jakoet-Salie, A., 2018, 'Co-production of trust for effective local governance: A case study of Nelson Mandela Bay Municipality', Unpublished thesis for the Degree of Doctor of Philosphiae, Faculty of Arts, Nelson Mandela University, Port Elizabeth.

John, P., Cotterill, S, Moseley, A., Richardson, L., Smith, G., Stoker, G. et al., 2011 Nudge, nudge, think, think: Using experiments to change civic behaviour, Bloomsbury Academic, London.

Karamoko, J. \& Jain, H., 2011, 'Community protests in South Africa: Trends, analysis and explanations', viewed 23 May 2017, from http://www.ldphs.org.za/ publications/publication-bytheme/local-government-in-south-africa/ communityprotests/Community_Protests_SA.pdf.

Keohane, R. \& Nye, J., 2000, 'Introduction', in J. Nye \& J. Donahue (eds.), Governance in a globalization world, pp. 136-158, Brookings Institution, Washington, DC.

Lindquist, E., Vincent, S. \& Wanna, J., 2013, Putting citizens first: Engagement in policy and service delivery for the 21st century, Griffin Press, Netley.

Mafunisa, M.J. \& Xaba, B., 2008, 'Public participation and the integrated development planning: The case of Limpopo Province', Journal of Public Administration 43(3.2), 452-460.

Mle, T.R., 2014, 'Potential benefits of monitoring and evaluation as a tool in the South African local government spheres', Africa's Public Service Delivery \& Performance Review Journal 2(1), 56-66. https://doi.org/10.4102/apsdpr.v2i1.43

National Planning Commission, 2011, National development plan 2030: Our futureMake it work, NPC, Pretoria.

Ostrom, E., 1996, 'Crossing the great divide: Co-production, synergy, and development', World Development 24, 6. https://doi.org/10.1016/0305-750X(96)00023-X

Pestoff, V., Brandsen, T. \& Verschuere, B., 2013, New public governance, the third sector and co-production, p. 48, Routledge, London.

Pillay, P., 2017, 'Public trust and good governance: A comparative study of Brazil and South Africa', African Journal of Public Affairs 9(8), 31-47.

Republic of South Africa, 1998, The White Paper on Local Government 9 March 1998' viewed 08 May 2015, from http://www.cogta.gov.za/cgta_2016/wp-content/ uploads/2017/05/white-paper-on-local-government.pdf

Republic of South Africa, 2005, Ward committee resource book, Government Printers, Pretoria.

Republic of South Africa, 2016, Statistics SA, viewed 03 April 2017, from http://www. statssa.gov.za/publications.

Rittenberry, J., 2018, 'South Africa: As trust falls, business expected to lead', viewed 28 October 2018, from https://www.edelman.com/post/south-africa-trust-fallsbusiness-expected-to-lead.

Shaidi, E.W., 2013, 'Investigation into the causes of service delivery protests in municipalities. A case of Nelson Mandela Bay Municipality', Unpublished thesis for the Degree of Doctor of Philosophiae, Faculty of Arts, Nelson Mandela Metropolitan University, Port Elizabeth.

Sithomola, T. \& Auriacombe, C., 2018, 'Developing a logic framework design as a methodological approach to monitoring and evaluation (M\&E)', African Journal of Public Affairs 10(3), 83-99.

Somdyala, K., 2018, 'Trust in South African government dips', viewed 13 November 2018, from https://www.news24.com/SouthAfrica/News/trust-in-sa-government-dipsbusinesses-most-trusted-survey-20180619.

South Africa, 1996, Constitution of the Republic of South Africa Act 1996, Government Printers, Pretoria.

South Africa, 1997, The white paper on transforming public service delivery, Government Printers, Pretoria.

South Africa, 1998, Local government: Municipal structures act 117 of 1998 Government Printers, Pretoria.

South Africa, 1998, The white paper on local government, Government Printers, Pretoria.

South Africa, 2000, Local government: Municipal systems act 32 of 2000, Government Printers, Pretoria.

South Africa, 2003, Local government: Municipal finance management act 56 of 2003, Government Printers, Pretoria.

Statistics South Africa (STATS SA), 2018, Major service delivery protests by 2005-2018, viewed 11 February 2019, from http://www.statssa.gov.za/publications

Tippett, J. \& Kluvers, R., 2010, 'Accountability and information in local government', World Journal of Management 2(3), 22-33.

Van der Waldt, G., Khalo, T., Nealer, E., Phutiagae, K., Van der Walt, C., Van Niekerk, D.E. et al., 2014, Municipal management. Serving the people, 2nd edn., Juta, Cape Town. 